\title{
CHOICE OF INDUSTRIAL RELOCATION WITH ASPECTS OF THE STAKEHOLDER: THE CASE OF FETHIYY INDUSTRIAL AREA
}

Erdoğan GAVCAR*, Ayşe ÇELIK YETIM **

* Muğla Sitkı Koçman Üniversitesi

E-mail: gavcar@mu.edu.tr*, aysecelik@mu.edu.tr**

Copyright (C) 2015 Erdoğan GAVCAR, Ayşe ÇELIK YETIM. This is an open access article distributed under the Eurasian Academy of Sciences License, which permits unrestricted use, distribution, and reproduction in any medium, provided the original work is properly cited.

\begin{abstract}
The purpose of the study is to reveal the aspects of the stakeholder on relocation of Fethiye industrial site. Question form has been used to collect data. In total, question form was applied to 338 stakeholders. This study has been carried out in October 2015. As a result of the study, most of the stakeholders agree to relocate the industrial area. The majority of the survey participants indicated "The Motocross Event Venue Area" as the relocation area. There is no significant statistical difference between the aspects of relocation area with gender, ownership status, education status and age range.According to result of the study, the suggestion presented for relocation area with the aspects of the stakeholder will contribute to choice of industrial relocation.
\end{abstract}

Keywords: Fethiye Industrial Area, Choice of Industrial Relocation, Stakeholder.

\section{Paydaş Bakış Açısı ile Yeni Kuruluş Yeri Seçimi: Fethiye Sanayi Sitesi Örneği}

\section{ÖZET}

Araştırmanın amacı, Fethiye sanayi sitesinin taşınmasına ilişkin paydaş görüşlerinin ortaya çıkarılmasıdır. Veri toplamada soru formu kullanılmıştır. Araştırma kapsamında hazırlanan soru formu toplamda 338 paydaşa uygulanmıştır. Bu araştırma Ekim 2015 tarihinde yapılmıştır.Araştırma sonucunda katılımcıların bir çoğu sanayi sitesinin taşınmasına ilişkin görüş belirtmişlerdir. Araştırmaya katılanların büyük çoğunluğu yeni sanayi sitesinin kuruluş yerinin "Motokros etkinliğinin yapıldığı yer" olması gerektiğini belirtmişlerdir. Araştırmaya katılanların kuruluş yerine ilişkin görüşleri cinsiyet, mülkiyet durumu, eğitim durumu ve yaş aralığına göre istatistiksel olarak anlamlı bir farklılık göstermemektedir. Araştırmada elde edilen sonuçlar doğrultusunda paydaş bakış açısı ile yeni sanayi sitesi kurulumuna ilişkin yer önerisi yeni kuruluş yeri seçimine katkı sağlayacaktır.

Anahtar Kelimeler: Fethiye Sanayi Sitesi, Yeni Kuruluş Yeri Seçimi, Paydaş.

\section{GíRiş}

Muğla ilinde yer alan Fethiye ilçesi yerli ve yabancı turistler tarafından tercih edilen bir destinasyondur. Yaz aylarında turist akımı ile birlikte nüfus artmaktadır. Bunun yanında destinasyonda sürekli yaşayan halk nüfusu da yıllara göre artış göstermektedir. Fethiye Sanayi 
Sitesinin yer aldığı bölgede şehirlerarası otobüs terminali ve alışveriş merkezinin yer alması bölgenin taşıma kapasitesi problemini gündeme getirmiştir.

$\mathrm{Bu}$ çalışmada, sanayi sitesinin yer değiştirme durumuna ilişkin paydaş görüşlerinin alınması hedeflenmiştir. Araştırma kapsamında a) Fethiye Sanayi Sitesi çalışanları, b) Karaçulha Sanayi Sitesi çalışanları, c) Fethiye'de yer alan esnaflar, d) alışveriş merkezi ve civarındaki esnaflar, e) sanayi sitesi civarında ve merkezde yaşayan halk, paydaş olarak belirlenmiştir. Sanayi sitesinin taşınmasına ilişsin görüşlerin alınmasına ilişkin hazırlanan soru formu aracılı̆̆ 1 ile görüşler alınmıştır.

\section{LITERATÜR TARAMASI}

Kuruluş yeri seçimi, bir işletmenin hangi arsa üzerinde kurulacağının karar verilmesi işlemidir (Eleren, 2006). Kuruluş yeri, verimin ortaya konulması için gerekli tesislerin olduğu yerdir (Ertürk, 1995: 62). Bir işletmeyi kurma faaliyeti sırasında işletmenin üretimini sürdüreceği konumun belirlenmesi birinci derecede önemlidir. Elverişsiz bir ortamda kurulan bir işletmenin bir yerden diğer bir yere aktarılması büyük harcamalar gerektirebileceği gibi, böyle bir yerde kurulan işletme, işletmenin ömrü boyunca gereksiz harcama ve zarara yol açabilir (Doğan, 2010: 113). Kuruluş yeri bir işletmenin uzun dönem faaliyetlerini gerçekleştireceği, en düşük maliyet ile en yüksek karı sağlayabilmeyi hedeflediği ve zaman içinde meydana gelebilecek değişikliklere de uyum sağlayabilecek bir alandır (Demirdöğen ve Bilgili, 2004).

Kuruluş yeri seçimini belirleyen birçok faktör bulunmaktadır. Risk bir ölçüt olabileceği gibi, maliyetler, karlılık, ulusal ekonomiye katkı, büyüme ve genişleme gibi faktörler de ölçüt olarak dikkate alınabilir. Genelde kuruluş yerinin seçiminde maliyetlerden yola çıkmak ve karlılık durumunu ölçüt olarak kullanma eğilimi, çoğunlukla tercih edilen bir yöntemdir. Buna göre kar maksimizasyonu esas alınarak kuruluş yeri seçimi, özellikle özel sektör yatırımlarında birinci derecede önem kazanmaktadır (Usta, 1997: 91).

Kuruluş yeri seçimine ilişkin farklı sektörlerde bir çok araştırma yapılmıştır. Bu uygulamalardan bazılarına bakıldığında; Tengilimoğlu (2001)'nun hastane, Tzeng, Tenga, Chenb ve Opricovic (2002)'in lokanta, Padilla (2002)'nın kütüphane, Cheng, Li ve Yu (2005)'nun alışveriş merkezi, Eleren (2006) deri sektörü, Birsel ve Cerit (2009)'in lojistik işletme, Xu, Wei, Shi ve Yang (2009)'ın dağıtım merkezi, Çınar (2010)'ın banka şubesi, Çatay (2011)'ın itfaiye istasyonu, Köksal ve Emirza (2011)'nın cadde mağazaları ve alışveriş merkezleri, Çiçekdağı ve Kırış (2012)'ın afet istasyonu toplanma merkezi, Arık, KaraaslanBalıkçı ve Alabaş-Uslu (2012)'nun de bir perakende firması ve Ar, Birdoğan ve Özdemir (2014)'in otel işletmesi için yer seçimi çalışması yaptığı görülmektedir.

Erzurum iline yönelik Demirdöğen ve Bilgili (2004) mevcut sanayi sitesine ek olarak yeni bir II. Organize sanayi kurulması aşamasında, alternatif bölgeler arasından yapılan yer seçimi kararını etkileyen faktörler ve bu faktörlerin önem düzeylerini belirlemek amaciyla yaptığ 1 çalışmada 33 KOBİ üzerinde bir araştırma yapmıştır.

Yıldız ve Şahin (2014) ise işletmelerin kuruluş yeri seçiminde göz önünde bulundurdukları faktörleri ve özellikle teşvik paketlerinin kuruluş yeri seçim kararlarında işletmelere etkisini belirlemek üzere bir çalışma yapmışlardır. Yapılan araştırmada; coğrafi konum, uygun iş gücü ortamı, arazi fiyatlarının uygunluğu, arazi bulabilme imkanının fazlalığı, pazara yakınlık, tedarikçilere ve kaynaklara yakınlık işletmelerin kuruluş yeri seçim kararlarında göz önünde bulundurdukları önemli faktörler olarak belirlenmiştir. İşletmelerinin kuruluş yeri seçimini etkileyen devlet teşvikleri ise; sigorta primi işveren hissesi desteği, vergi indirimi, yatırım yeri tahsisi ve KDV istisnası olarak belirlenmiştir.

Ar, Baki ve Özdemir (2014) çalışmalarında Rize'de kurulması planlanan bir ekoturizm merkezi için yer seçim uygulaması gerçekleştirmişlerdir. Çok kriterli karar verme problemi 
olarak değerlendirilebilecek bu problemin çözümünde bulanık Analitik Hiyerarşi Süreci (AHS) ve bulanık VIKOR yöntemleri kullanılmıştır. Araştırma sonucunda "yakın çevre" kriteri yer seçim kararında en önemli kriter olarak belirlenirken otel yeri olarak üç alternatiften Kuspa seçilmiştir.

Kuruluş yeri seçiminde kullanılan birçok yöntem bulunmaktadır. Bu yöntemler kendi aralarında matematiksel yöntemler, finansal yöntemler, simülasyon yöntemi ile son zamanlarda öne çıkan ve hiyerarşiyi dikkate alan çok kriterli karar verme tekniklerinden Analitik Hiyerarşi Süreci, TOPSIS, Fuzz TOPSIS, Fuzzy AHS,.vb yöntemler örnek gösterilebilir (Eleren, 2006). Bunun yanında kuruluş yerinin belirlenmesinde paydaşlardan da yararlanılabilir. Planlanan işletmenin yeni kuruluş yeri paydaşları ilgilendirecek olmasından dolayı söz konusu grupların fikrinin alınması önem taşımaktadır.

Son yıllarda paydaş teorisi üzerine bir çok çalışma yapılmıştır. Paydaş teorisine ilişkin 1995 yılına kadar yüzün üzerinde çalışma yapıldığı Donaldson ve Preston (1995:65) tarafından belirtilmiştir (Friedman, 2002: 1). Freeman'a göre paydaş " işletmenin başarısından etkilenen ve/veya işletmenin başarısını etkileyen kişi veya gruplar" (1984:46) olarak tanımlanmıştır. Paydaş olarak adlandırılan bu kişi ya da gruplar, hissedarları, çalışanları, tedarikçileri, müşterileri, yerel halkı, banka ve diğer kredi veren kuruluşları, hükümeti, farklı çıkar gruplarını ve gerçekte faaliyetleri ile işletmeyi etkileyen ve işletmenin faaliyetlerinden etkilenen tüm kesimleri içermektedir.

\subsection{Fethiye}

Fethiye antik dönemde Likya-Karya sınırı içerisinde yer alan bir kıyı kentidir. Fethiye'nin Antik Çağlardaki adı Telmessos'dur. Kuruluşuna ilişkin kesin bir bilgi olmamakla birlikte kentin bilinen en eski yazılı belgelere göre M.Ö. V. yüzyıldan beri var olduğu tahminlenmektedir. Telmessos uzun süre Likya'dan ayrı bağımsız bir kent olarak varlığını sürdürmüştür. Kent sırasıyla Pers, Büyük İskender, Roma, Bergama Krallı̆̆ı, Bizans, Menteşeoğulları ve Osmanlıların egemenliğinde kalmıştır (Kültür ve Turizm Bakanlığı, Tanitma Genel Müdürlüğü, 2014).

Doğa güzellikleri ve zenginlikleri ile olduğu kadar da tarihi ve turistik önemiyle dikkati çeken Fethiye ilçesi; Anadolu'nun Güneybatısında, 3700 Kuzey, 36 15' 28 50'batı, 2950 doğu boylamı çizgileri arasında, güneyde Eşen Çayı'nın Akdeniz'e döküldüğü Çayağzı; ve Kaş ilçesi, batıda Kapıdă̆ Yarımadası ve Dalaman İlçesi; doğuda Korkuteli, Elmalı, kuzeyinde Gölhisar ve Çameli İlçeleriyle çevrili olarak,Akdeniz bölgesi ile Ege bölgesini ayıran hattın Akdeniz bölgesi içinde kalan tipik bir kıyı kentidir (Fethiye Kaymakamlığı, 2014).

Yüzölçümü 2686,411 Km2 olup, önemli Akarsuları Karg1 ve Eşen çayıdır. En yüksek dağları sırasıyla Babadağ, Akdağ, Mendos ve Girdev Dağları teşkil etmektedir. Önemli ovaları Eşen ve Fethiye ovalarıdır. İlçe hudutlarında birbirinden güzel çoğunluğu Denize dik olarak inen 180 koy-körfez bulunmaktadır. Kıyı uzunluğu 167 Km. olan İlçede 18 adet ada mevcut olup, bu adaların önemlileri Şövalye, Kızılada, Katrancı, Tersane, Domuz, Yassıca, Gemile, Ayanikola, Karacaören adalarıdır. Karakteristik Akdeniz ikliminin görüldüğü ilçede; Yazlar sıcak ve kurak, kışlar 1lık ve yağışlı geçer. İlçe yüzölçümünün \%72'lik bölümü ormanlık ve makiliklerle alanlarla kaplıdır (Fethiye Kaymakamlığı, 2014).

Adrese dayalı nüfus sonuçlarına göre 2013 yılındaki Fethiye ilçesinin toplam nüfusu 140.509 kişidir. Fethiye nüfusunun 69.700 (\%49.61) kişisini kadın; 70.809 $(\% 50,39)$ 'unu erkek nüfus oluşturmaktadır (http://www.fethiye.gov.tr/default_B0.aspx?content=194).

Fethiye körfezin doğusunda yer alan ilçe, Likya bölgesinin tarihi zenginliklerine yakın oluşu, alternatif turizm çeşitlerini sunması ve doğal güzellikleri ile Türkiye'nin gözde turizm 
merkezlerinden biri halindedir. Muğla iline 2013 yılında 3078781 yabancı ziyaretçi, 143534 yerli ziyaretçi toplam 3222315 turist girişi gerçekleşmiştir (Muğla İl Kültür ve Turizm Müdürlügü̈, 2013). Fethiye'yi 2012 yılında 650.000 yabanc1, 600.000 yerli turist; 2013 yılında 650.000 yabanc1, 650.000 yerli turist; 2014 y1lında 650.000 yabanc1, 650.000 yerli turist ziyaret etmiştir (Fethiye Turizm Danışma Bürosu). Fethiye ekonomisi turizmin yanında büyük ölçüde tarım ve hayvancılığa dayanmaktadır. Toplam tarım alanı 64.395 hektar olup bunun \%40'1 (25.841 Hektar) kuru tarım alanı, \%60'si ise (38.554 Hektar) sulanabilir tarım alanı niteliğini taşımaktadır (Fethiye Kaymakamlığı, 2014).

Fethiye yüksek öğretim alanında gelişme göstermektedir. Fethiye İşletme Fakültesi, Fethiye Sağlık Yüksekokulu, Fethiye Ali Sıtkı Mefharet Koçman Meslek Yüksekokulu Muğla Sitkı Koçman Üniversitesi bünyesinde faaliyet göstermektedir. Fethiye İşletme Fakültesi'nin 2011/2260 sayılı Bakanlar Kurulu Kararı'nın 24 Ekim 2011 tarihli ve 28094 sayılı Resmi Gazete'de yayınlanması ile kuruluş süreci tamamlanmıştır. Fethiye İşletme Fakültesinde, İşletme, Turizm İşletmeciliği, Ekonomi ve Finans, Uluslararası Ticaret ve Lojistik ile Yönetim Bilişim Sistemleri bölümleri yer almaktadır (Fethiye İşletme Fakültesi, 2014).

\subsection{Fethiye Sanayi Sitesinin Taşınması}

Organize Sanayi Bölgeleri (OSB): Ağır Sanayi ve entegre tesisler dışında kalan, çeşitli sektörel üretimleri uyumlu ve birbiriyle tamamlayıcı bir nitelikte olan küçük ve/veya orta sanayi ölçek ve boyutundaki imalat ünitelerinin, kapsamlı bir biçimde sınırları tayin edilmiş bir alanda, yerleşimi, altyapısı, gerekli sosyal ve teknik hizmetleri ve ortak yapıları ile organize edilmiş bölgeleridir. Burada önemli bir özellik, yerleşimin ortak amaca uygun olması, altyapının gereksinmelerin tamamını karşılaması, bina ve tesis açık alanları ile tesisatlarının belirli kriterlere göre standartlaşmasıdır. Keza istihdamın kentleşme olgusu ile birlikte sağlıklı ve gelişime açık olması, bölge ortak yapılarının tüm ihtiyaçları karşılaması istenmektedir (Bayülken ve Kütükoğlu, 2012: 1).

Küçük Sanayi Siteleri (KSS): Genellikle aynı üretim kolunda, çeşitli mal ve hizmet imalatına yönelik atölye ve küçük fabrika ünitelerine çeşitli olanaklar sağlayan, altyapı ve gerekli sosyal-teknik hizmetleri ortak, diğer bakışla, esnaf ve sanatkârların toplandığı dükkân şeklindeki sanayi çarşıları da çok küçük ölçekli sınaî altyapı organizasyonları olarak ele alınabilir. Ortak özellik, satış hacmi, istihdam yapısı ve üretim yelpazesi ile sınırlı, küçük ölçek ve boyutlu atölyeleri içermesidir (Bayülken ve Kütükoğlu, 2012: 1).

507 sayılı Esnaf ve Sanatkârlar Kanunu'na göre: ticari kazanc1, daha çok beden gücüne dayanan, genellikle kendi başına çalışan ve tüccar sayılamayacak kimselere esnaf denilmektedir. 507 sayılı Esnaf ve Sanatkârlar Kanunu'nun 1. Maddesine göre: (Değişik:2/5/1983 - KHK 62/1 md;Aynen kabul: 14/2/1985 - 3153/1 md.) (http://www.tesk.org.tr/tr/5362/507.php) Esnaf ve sanat sahipleriyle bunların yanlarında çalışanların müşterek ihtiyaçlarını karşılamak, mesleki faaliyetlerini kolaylaştırmak, mesleğin genel menfaatlerine uygun olarak gelişmesini sağlamak, meslek mensuplarının birbirleriyle ve halk ile olan ilişkilerinde dürüstlüğü ve güveni hakim kılmak üzere meslek disiplini ve ahlakını korumak maksadıyla kurulan kamu kurumu niteliğinde tüzelkişiliğe sahip meslek kuruluşlarına Esnaf ve Sanatkarlar Odası denir. Söz konusu maddede yer alan Fethiye esnaf ve sanatkarların "mesleki faaliyetlerini kolaylaştırmak" ifadesini Fethiye bölgesinde daha etkin hale getirebilmek amacıyla "Sanayi Sitesinin Taşınması"na ilişkin bu araştırma yapılmaktadır.

Sanayi sitesinin taşınılmasına ilişkin yerler a)Sarıkız Mevkii, b)Motokros etkinliğinin yapıldığı yer, c)Yakacık-Zorlar Sınırı olarak belirlenmiştir. 


\section{METODOLOJI}

\subsection{Araştırmanın Amacı}

Bu araştırmanın amacı Fethiye'de yer alan sanayi sitesi mensuplarının, mevcut sanayi sitesi civarında yer alan esnaf, Fethiye'de yer alan esnaf ve sanatkarlar ile yerel halkın sanayi sitesinin taşınmasına ilişkin görüşlerini ortaya koymaktır. Araştırmanın alt amaçları aşağıdaki gibi siralanmaktadir;

a) Fethiye Sanayi Sitesinde faaliyet gösteren esnaf profilinin belirlenmesi,

b) Karaçulha Sanayi Sitesinde faaliyet gösteren esnaf profilinin belirlenmesi,

c) "Sanayi sitesi taşınmalı mı?" sorusuna ilişkin görüşlerin ortaya çıkarılması,

d) "İkinci bir sanayi sitesi kurulmalı mı?" sorusuna ilişkin görüşlerin ortaya çıkarılması,

e) Sanayi sitesi kuruluş yerine ilişkin görüşlerin belirlenmesidir.

\subsection{Araştırmanın Kapsamı ve Hipotezleri}

Araştırma Fethiye'de yer alan sanayi sitesi mensuplarını, mevcut sanayi sitesi civarında yer alan esnaf, Fethiye'de yer alan esnaf ve sanatkarlar ile yerel halk1 kapsamaktadır.

\section{Araştırmanın Hipotezleri}

H1: Araştırmaya katılanların, sanayi sitesinin taşınacağı yere ilişkin görüşleri cinsiyete göre anlamlı bir farklılık göstermektedir

H2: Araştırmaya katılanların, sanayi sitesinin taşınacağı yere ilişkin görüşleri mülkiyet durumlarına göre anlamlı bir farklılık göstermektedir.

H3: Araştırmaya katılanların, sanayi sitesinin taşınacağı yere ilişkin görüşleri taşınma kararlarına göre anlamlı bir farklılık göstermektedir.

H4: Araştırmaya katılanların, sanayi sitesinin taşınacağı yere ilişkin görüşleri ikinci bir sanayi bölgesi açılmasına ilişkin görüşlerine göre anlamlı bir farklılık göstermektedir.

H5: Sanayi sitesi kurulumuna ilişkin görüş, eğitim düzeyine göre anlamlı bir farklılık göstermektedir.

H6: Sanayi sitesi kurulumuna ilişkin görüş, yaş aralığına göre anlamlı bir farklılık göstermektedir.

\section{3. Örneklem Seçimi}

Araştırmanın evrenini, Fethiye Esnaf ve Sanatkarlar odasına kayıtlı esnaflar ve Fethiye'de yaşayan halk oluşturmaktadır. Araştırmanın örneklemini ise Sanayi Esnafının faaliyet gösterdiği Fethiye Sanayi Sitesi ve Karaçulha Sanayi Sitesinde yer alan sanayi esnafi; Fethiye sanayi sitesi ve alışveriş merkezi civarında faaliyet gösteren esnaf ile Fethiye merkezde ve alışveriş merkezi civarında yer alan vatandaşlar oluşturmaktadır.

Karaçulha bölgesinde Sanayi odasına kayıtlı çeşitli faaliyet alanlarında toplam 273 esnaf bulunmaktadır. Karaçulha Sanayi Sitesinde motor tamir, traktör tamir, oto kaporta ve boya, oto elektrikçisi, mobilet ve bisiklet tamircisi, oto yedek parça satıcısı vb. faaliyetlerde bulunan ve sanayi bölgesi taşınması durumunda mekan değişikliği yapacak toplam 34 işletme Karaçulha Sanayi Sitesinde yer almaktadır. Fethiye Taşyaka Mahallesi sınırları içerisinde yer alan toplam 569 esnaf bulunmaktadır. Fethiye Sanayi Sitesinde ise oto tamircisi, oto döşeme, oto kaporta ve boya, motor tamircisi, oto yedek parça satıcısı, oto makasçı, oto egzoz tamiratçısı, oto gaz dönüşüm servisi, oto cam esnafi, lastikçi, rot balans ayar işi yapan esnaf, bobinaj tamiratı, balatacı tornacı, demir doğramacı, mermerci, marangoz, mobilya imalatçısı, hırdavatçı, PVC plastik doğrama vb. iş kolları faaliyet göstermektedir.

Araştırmada veri toplamak için anket tekniği kullanılmıştır. Veri toplamak amacıyla oluşturulan anketin ön testi yapılarak kullanılabilirliği ortaya çıkarılmıştır. Ankette yer alan 11 sorunun 7'si seçmelik, 2'si boşluk doldurmalı ve 2'si açık uçlu sorulardan oluşmaktadır. Anket uygulaması 30-31 Ekim tarihleri arasında anketörler (7 anketör) aracılığı ile 
gerçekleştirilmiştir. Yüz yüze uygulanan anket sonucunda kullanılabilir 338 ankete ulaşılmıştır. SPSS istatistik analiz paket programı aracılığı ile verilerin frekans analizi ve farklılık testleri yapılmıştır.

\subsection{Araştırmanın Bulguları}

Verilerin analizinde frekans, $\mathrm{t}$ testi ve farklılık analizleri kullanılmıştır.

Tablo 1. Anket Uygulanan Örneklemin Dağılımı

\begin{tabular}{|l|r|r|}
\hline Anket Uygulanan Yerler & Sayı (f) & \multicolumn{1}{c|}{ Yüzde (\%) } \\
\hline Fethiye Sanayi Sitesi & 108 & 32,0 \\
\hline Karaçulha Sanayi Sitesi & 34 & 10,1 \\
\hline Fethiye Merkezde Yer Alan Esnaflar & 32 & 9,5 \\
\hline Alış Veriş Merkezi (AVM) Civarı Esnafi & 44 & 13,0 \\
\hline Sanayi ve AVM Civarı Vatandaş & 45 & 13,3 \\
\hline Merkezde Bulunan Vatandaş & 75 & 22,2 \\
\hline Toplam & $\mathbf{3 3 8}$ & $\mathbf{1 0 0 , 0}$ \\
\hline
\end{tabular}

Tablo 1'de anket uygulama yerlerinin dağılımı bulunmaktadır. Fethiye Sanayi Sitesi'nden 108 esnaf (\%32); Fethiye Merkez'de bulunan 75 vatandaş (\%22,2); Sanayi ve AVM Civarında bulunan 45 (\%13,3) Vatandaş; AVM civarında bulunan 44 esnaf (\%13); Karaçulha Sanayi Sitesinden 34 sanayi esnafi (\%10,1); Fethiye merkezde yer alan 32 esnaf $(\% 9,5)$ ankete katılan katılımcıları oluşturmaktadır.

Tablo 2: Araştırmaya Katılanlara İlișkin Demografik Bilgiler

\begin{tabular}{|c|c|c|c|c|c|}
\hline & $\begin{array}{l}\text { Frekans } \\
\text { (f) }\end{array}$ & $\begin{array}{l}\text { Yüzde } \\
(\%)\end{array}$ & & $\begin{array}{l}\text { Frekans } \\
\text { (f) }\end{array}$ & $\begin{array}{l}\text { Yüzde } \\
\text { (\%) }\end{array}$ \\
\hline Cinsiyet & & & & & \\
\hline Kadın & 43 & 13.0 & Ĕ̈itim & & \\
\hline Erkek & 289 & 87.0 & Durumu & & \\
\hline Toplam & 332 & 100,0 & & 111 & 34,4 \\
\hline Yaş & & & Illkokul & 76 & 23,5 \\
\hline 20 ve alt 1 & 17 & 5.1 & Ortaokul & 90 & 27,9 \\
\hline $21-30$ & 65 & 19.4 & Lise & 20 & 6,2 \\
\hline $31-40$ & 106 & 31.6 & Önlisans & 25 & 7,7 \\
\hline $41-50$ & 95 & 28.4 & Lisans & 1 & 0,3 \\
\hline $51-60$ & 34 & 10.1 & Lisansüstü & 323 & 100,0 \\
\hline 61ve üzeri & 18 & 5.4 & Toplam & & \\
\hline Toplam & 335 & 100.0 & & & \\
\hline
\end{tabular}

Tablo 2'de ankete katılanların cinsiyet dağılıma ilişkin bilgiler yer almaktadır.Ankete katılanların 289'unu erkek, 43'ünü ise kadın denekler oluşturmaktadır. Erkekler dağılımın \%87'sini oluştururken kadınlar \%13'ünü oluşturmaktadır.

Tablo 2'de ankete katılanların yaş dağılımına ilişkin bilgiler yer almaktadır. Ankete katılanların 106'sı (\%31,6) 31-40 yaş aralığında; 95'i $(\% 28,4)$ 41-50 yaş aralığında; 65'i $(\% 19,4)$ 21-30 yaş aralığında; 34'ü $(\% 10,1)$ 51-60 yaş aralığında; 18 'i $(\% 5,4) 61$ ve üzeri yaş aralığında; 17 'si $(\% 5,1)$ ise 20 ve altı yaş aralığında yer almaktadır. 
Tablo 3: Araştırmaya katılanların Faaliyet Durumları ve Taşınma Görüşlerine İlişkin Bilgiler

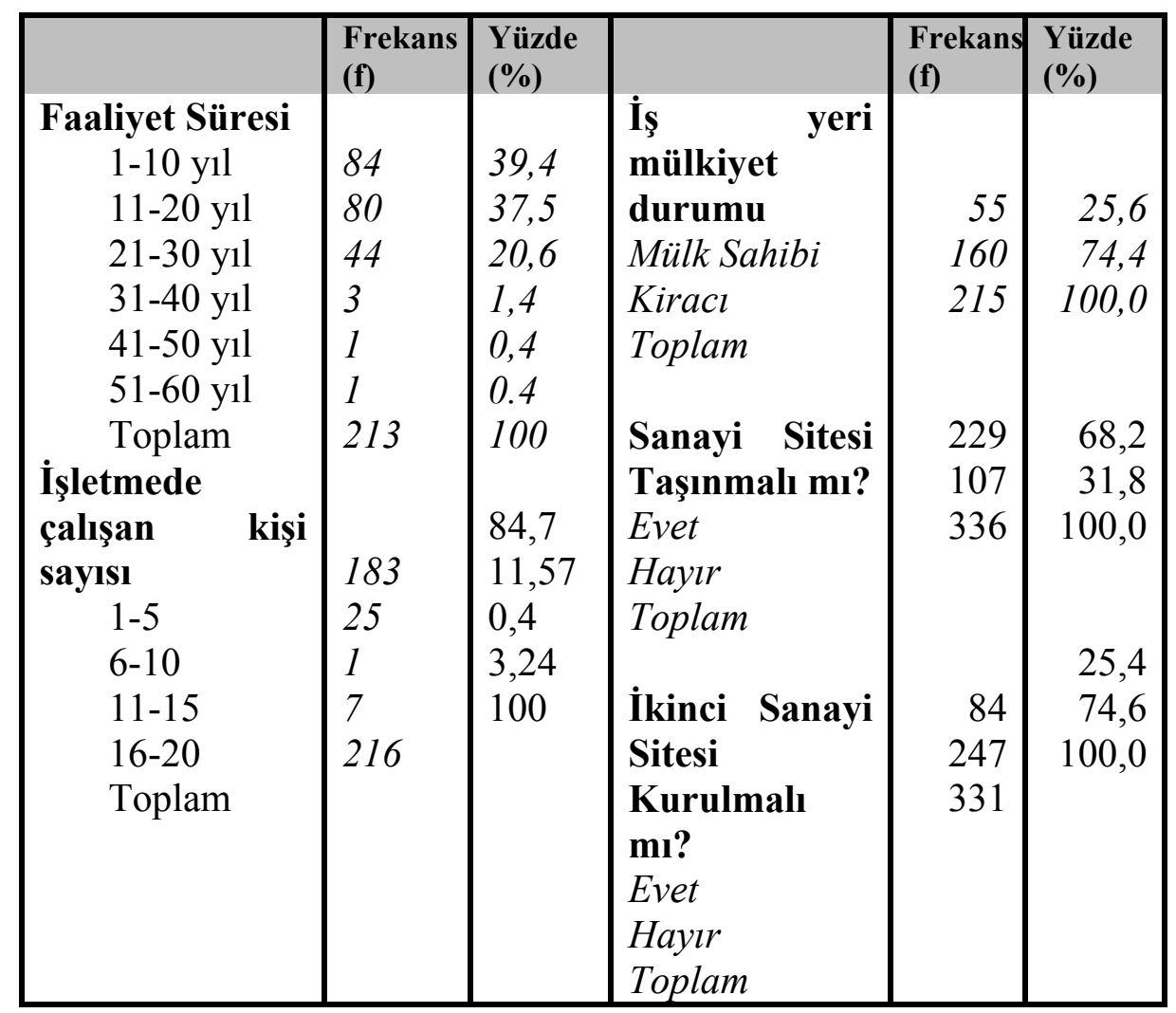

Tablo 3'de ankete katılan işletmelerin faaliyet sürelerine ilişkin veriler yer almaktadır. Araştırmaya katılanların faaliyet süreleri 1-60 yıl arasında yer almaktadır. Faaliyet süresi bağlamında en yüksek frekansa sahip yıllar 20 yıl (21 işletme), 8 yıl (19 işletme), 15 yıl (18 işletme), 5 yıl (14 işletme) olarak sıralanmaktadır.

Tablo 3'de ankete katılan işletmelerde çalışan kişi sayısına ilişkin bilgiler yer almaktadır. Ankete katılan 67 işletme $(\% 31,2) 1$ çalışan, 47 işletme $(\% 21,9) 2$ çalışan, 26 işletme $((\% 12,1) 3$ ve 4 çalışan, 17 işletme $(\% 7,9)$ 5çalışan ile en yüksek frekans değerlerine sahiptir.

Tablo 3'de ankete katılan işletmelerin iş yeri mülkiyet durumuna ilişkin veriler yer almaktadır. Ankete katılanların 160'1 $(\% 74,4)$ kiracı; 55'i $(\% 25,6)$ mülk sahibi olarak faaliyet göstermektedir.

Tablo 3'de ankete katılanların sanayi sitesinin tamamen taşınmayıp ikinci bir sanayi sitesinin kurulmasına ilişkin görüşleri yer almaktadır. Ankete katılan 247 kişi $(\% 74,6)$ ikinci bir sanayi sitesinin kurulmadan sanayi sitesinin tamamının tek bir noktaya kurulması görüşünü; 84 kişi $(\% 25,4)$ ise ikinci bir sanayi sitesinin kurulmasını mevcut sanayi sitesinde de faaliyet gösterilmesi görüşünü belirtmişlerdir. 
Tablo 4. Ankete Katılanların Yeni Sanayi Sitesinin Yeri Konusundaki Düşünceleri

\begin{tabular}{|l|r|r|}
\hline Yeni Sanayi Yeri & \multicolumn{1}{|c|}{ Sayı } & \multicolumn{1}{c|}{ Yüzde } \\
\hline Motokros Etkinliğinin Yapıldığı Mevkii & 216 & 68,8 \\
\hline Sarıkız Mevkii & 33 & 10,5 \\
\hline Yakacık-Zorlar Sınırı & 45 & 14,3 \\
\hline Diğer & 20 & 6,4 \\
\hline Toplam & $\mathbf{3 1 4}$ & $\mathbf{1 0 0 , 0}$ \\
\hline
\end{tabular}

Ankete katılanların yeni sanayi sitesinin kurulmasına ilişkin görüşleri tablo 4'de yer almaktadır. Ankete katılan 216 kişi $(\% 68,8)$ "Motokros etkinliğinin yapıldığı yer"; 45 kişi (\%14,3) "Yakacık-Zorlar Sınırı"; 33 kişi (\%10,5) "Sarıkız Mevkii"; ve 20 kişi $(\% 6,4)$ "Diğer" görüşünü vermişlerdir.

Tablo 5. Mülkiyete Göre Anket Uygulanan Bölgelerin Dağılımı

\begin{tabular}{|c|c|c|c|c|c|}
\hline \multirow[b]{2}{*}{ Mülkiyet Durumu } & \multicolumn{4}{|c|}{ Bölgesi } & \multirow[b]{2}{*}{ Toplam } \\
\hline & $\begin{array}{c}\text { Fethiye } \\
\text { Sanayi Sitesi }\end{array}$ & $\begin{array}{c}\text { Karaçulha } \\
\text { Sanayi Sitesi }\end{array}$ & $\begin{array}{c}\text { Fethiye } \\
\text { Merkezde } \\
\text { Yer Alan } \\
\text { Esnaflar }\end{array}$ & $\begin{array}{l}\text { AVM } \\
\text { Civarı } \\
\text { Esnafi }\end{array}$ & \\
\hline \multirow[t]{2}{*}{ Mülk Sahibiyim } & 35 & 2 & 4 & 14 & 55 \\
\hline & $63,6 \%$ & $3,6 \%$ & $7,3 \%$ & $25,5 \%$ & $100,0 \%$ \\
\hline \multirow[t]{2}{*}{ Kiracıyım } & 73 & 32 & 26 & 29 & 160 \\
\hline & $45,6 \%$ & $20,0 \%$ & $16,3 \%$ & $18,1 \%$ & $100,0 \%$ \\
\hline \multirow[t]{2}{*}{ Toplam } & 108 & 34 & 30 & 43 & 215 \\
\hline & $50,2 \%$ & $15,8 \%$ & $14,0 \%$ & $20,0 \%$ & $100,0 \%$ \\
\hline
\end{tabular}

Mülkiyet durumuna göre anket uygulama yerlerinin karş1laştırıldığı tablo 5'e göre Fethiye Sanayi Sitesinde yer alan $108(\% 50,2)$ esnafinın 35'i $(\% 63,6)$ mülk sahibi, 73'ü $(\% 45,6)$ kiracı; Karaçulha Sanayi Sitesinde yer alan $34(\% 15,8)$ esnafının 2'si $(\% 3,6)$ mülk sahibi, 32'si (\%20) kiracı; Fethiye merkezde yer alan $30(\% 14)$ esnafin 4'ü $(\% 7,3)$ mülk sahibi, 30'u (\%16,3) kiracı; AVM civarında yer alan $43(\% 20)$ esnafın 14'ü $(\% 25.5)$ mülk sahibi, 29'u $(\% 18,1)$ kiracı olduğu görülmektedir. 
Tablo 6. Sanayi Sitesinin Taşınma Durumuna İlişkin Görüşlerin Bölgelere Göre Dağılımı

\begin{tabular}{|c|c|c|c|c|c|c|c|}
\hline \multirow[b]{2}{*}{$\begin{array}{l}\text { Sanayi } \\
\text { Bölgesi } \\
\text { Taşınmalı } \\
\text { M1 }\end{array}$} & \multicolumn{6}{|c|}{ Bölgesi } & \multirow[b]{2}{*}{ Toplam } \\
\hline & $\begin{array}{c}\text { Fethiye } \\
\text { Sanayi } \\
\text { Sitesi }\end{array}$ & $\begin{array}{c}\text { Karaçulha } \\
\text { Sanayi } \\
\text { Sitesi }\end{array}$ & $\begin{array}{l}\text { Fethiye } \\
\text { Merkezde } \\
\text { Yer Alan } \\
\text { Esnaflar }\end{array}$ & $\begin{array}{l}\text { AVM } \\
\text { Civarı } \\
\text { Esnafi }\end{array}$ & $\begin{array}{c}\text { Sanayi } \\
\text { ve AVM } \\
\text { Civarı } \\
\text { Vatandaş }\end{array}$ & $\begin{array}{c}\text { Merkezde } \\
\text { Bulunan } \\
\text { Vatandaş }\end{array}$ & \\
\hline \multirow[t]{2}{*}{ Evet } & 50 & 29 & 19 & 28 & 37 & 66 & 229 \\
\hline & $21,8 \%$ & $12,7 \%$ & $8,3 \%$ & $12,2 \%$ & $16,2 \%$ & $28,8 \%$ & $100,0 \%$ \\
\hline \multirow[t]{2}{*}{ Hayır } & 58 & 5 & 13 & 14 & 8 & 9 & 107 \\
\hline & $54,2 \%$ & $4,7 \%$ & $12,1 \%$ & $13,1 \%$ & $7,5 \%$ & $8,4 \%$ & $100,0 \%$ \\
\hline \multirow[t]{2}{*}{ Toplam } & 108 & 34 & 32 & 42 & 45 & 75 & 336 \\
\hline & $32,1 \%$ & $10,1 \%$ & $9,5 \%$ & $12,5 \%$ & $13,4 \%$ & $22,3 \%$ & $100,0 \%$ \\
\hline
\end{tabular}

"Sanayi sitesi taşınmalı mı?" sorusuna Fethiye Sanayi Sitesinde yer alan $108(\% 32,1)$ esnafın 50'si $(\% 21,8)$ evet, 58'i $(\% 54,2)$ hayır; Karaçulha Sanayi Sitesinde yer alan 34 $(\% 10,1)$ esnafin 29 'u $(\% 12,7)$ evet, 5'i $(\% 4,7)$ hayır; Fethiye Merkezde yer alan $32(\% 9,5)$ esnafin 19'u $(\% 8,3)$ evet, 13'ü $(\% 12.1)$ hayır; AVM civarında yer alan $42(\% 13,4)$ esnafin 37 'si $(\% 16,2)$ evet, 8'i $(\% 7,5)$ hayır; Fethiye Sanayi Sitesi ve AVM civarında yer alan 45 $(\% 13,4)$ vatandaşın 37'si $(\% 16,2)$ evet, 8'i $(\% 7,5)$ hayır; merkezde bulunan $75(\% 22,3)$ vatandaşın 66's1 $(\% 28,8)$ evet, 9'u $(\% 8,4)$ hayır cevabını vermiştir. Tabloda yer alan grup toplamları (336 esnaf ve vatandaş) dikkate alındığında 229 kişi sanayi sitesi taşınmalı, 107 kişi ise sanayi sitesi taşınmamalı cevabını vermiştir.

Tablo 7. İkinci Sanayi Sitesi Kurulmasına İlișkin Görüşlerin Bölgelere Göre Dağılımı

\begin{tabular}{|c|c|c|c|c|c|c|c|}
\hline \multirow{2}{*}{ 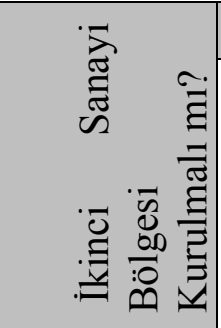 } & \multicolumn{6}{|c|}{ Bölgesi } & \multirow[b]{2}{*}{ Toplam } \\
\hline & $\begin{array}{c}\text { Fethiye } \\
\text { Sanayi } \\
\text { Sitesi }\end{array}$ & $\begin{array}{c}\text { Karaçulha } \\
\text { Sanayi } \\
\text { Sitesi }\end{array}$ & $\begin{array}{l}\text { Fethiye } \\
\text { Merkezde } \\
\text { Yer Alan } \\
\text { Esnaflar }\end{array}$ & $\begin{array}{c}\text { AVM } \\
\text { Civarı } \\
\text { Esnafı }\end{array}$ & $\begin{array}{c}\text { Sanayi } \\
\text { ve AVM } \\
\text { Civarı } \\
\text { Vatandaş }\end{array}$ & $\begin{array}{c}\text { Merkezde } \\
\text { Bulunan } \\
\text { Vatandaş }\end{array}$ & \\
\hline \multirow[t]{2}{*}{ Evet } & 44 & 3 & 16 & 13 & 7 & 1 & 84 \\
\hline & $52,4 \%$ & $3,6 \%$ & $19,0 \%$ & $15,5 \%$ & $8,3 \%$ & $1,2 \%$ & $100,0 \%$ \\
\hline \multirow[t]{2}{*}{ Hayır } & 63 & 31 & 12 & 29 & 38 & 74 & 247 \\
\hline & $25,5 \%$ & $12,6 \%$ & $4,9 \%$ & $11,7 \%$ & $15,4 \%$ & $30,0 \%$ & $100,0 \%$ \\
\hline \multirow[t]{2}{*}{ Toplam } & 107 & 34 & 28 & 42 & 45 & 75 & 331 \\
\hline & $32,3 \%$ & $10,3 \%$ & $8,5 \%$ & $12,7 \%$ & $13,6 \%$ & $22,7 \%$ & $100,0 \%$ \\
\hline
\end{tabular}

Tablo 7'de "İkinci sanayi sitesi kurulmalı mıdır?"sorusunun gruplara göre dağılımı yer almaktadır. Fethiye Sanayi sitesinde yer alan 107 (\%32,3) sanayi mensubunun 44'ü $(\% 52,4)$ evet, 63'ü $(\% 25,5)$ hayır; Karaçulha sanayi sitesinde yer alan toplam $34(\% 10,3)$ Karaçulha sanayi mensubunun 3'ü $(\% 3,6)$ evet, 31'i $(\% 12,6)$ hayır; Fethiye merkezde yer alan toplam 28 $(\% 8,5)$ esnafin 16'sı (\%19) evet, 12 'si $(\% 4,9)$ hayır; AVM civarı toplam $42(\% 12,7)$ esnafin 13 'ü $(\% 15,5)$ evet, 29 'u $(\% 11,7)$ hayır; sanayi ve AVM civarında yer alan toplam $45(\% 13,6)$ vatandaşın 7'si $(\% 8,3)$ evet, 38'si $(\% 15,4)$ hayır; merkezde bulunan toplam $75(\% 22,7)$ vatandaşın 1'i (\%1.2) evet, 74'ü (\%30) hayır cevabını vermiştir. Tabloda yer alan grup 
toplamları (331 esnaf ve vatandaş) dikkate alındığında 247 kişi ikinci bir sanayi bölgesi kurulmamalı, 84 kişi ise ikinci bir sanayi bölgesi kurulmalı cevabını vermiştir.

Tablo 8. Sanayi Bölgesinin Kuruluş Yerine İlişkin Görüşlerin Bölgelere Göre Dağılımı

\begin{tabular}{|c|c|c|c|c|c|c|c|}
\hline \multirow[b]{2}{*}{ 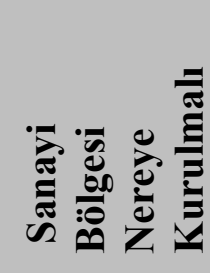 } & \multicolumn{6}{|c|}{ Bölgesi } & \multirow[b]{2}{*}{ Toplam } \\
\hline & $\begin{array}{c}\text { Fethiye } \\
\text { Sanayi } \\
\text { Sitesi } \\
\end{array}$ & $\begin{array}{c}\text { Karaçulha } \\
\text { Sanayi } \\
\text { Sitesi } \\
\end{array}$ & $\begin{array}{c}\text { Fethiye } \\
\text { Merkezde } \\
\text { Yer Alan } \\
\text { Esnaflar } \\
\end{array}$ & $\begin{array}{l}\text { AVM } \\
\text { Civarı } \\
\text { Esnafi } \\
\end{array}$ & $\begin{array}{c}\text { Sanayi } \\
\text { ve AVM } \\
\text { Civarı } \\
\text { Vatandaş }\end{array}$ & $\begin{array}{c}\text { Merkezde } \\
\text { Bulunan } \\
\text { Vatandaş }\end{array}$ & \\
\hline \multirow{2}{*}{$\begin{array}{l}\text { Motokros } \\
\text { Etkinliğinin } \\
\text { Yapıldı } \breve{g}_{1} \\
\text { Yer }\end{array}$} & 81 & 17 & 11 & 28 & 25 & 54 & 216 \\
\hline & $37,5 \%$ & $7,9 \%$ & $5,1 \%$ & $13,0 \%$ & $11,6 \%$ & $25,0 \%$ & $100,0 \%$ \\
\hline \multirow{2}{*}{$\begin{array}{l}\text { Sarıkız } \\
\text { Mevkii }\end{array}$} & 7 & 0 & 5 & 8 & 10 & 3 & 33 \\
\hline & $21,2 \%$ & $0,0 \%$ & $15,2 \%$ & $24,2 \%$ & $30,3 \%$ & $9,1 \%$ & $100,0 \%$ \\
\hline \multirow{2}{*}{$\begin{array}{l}\text { Yakacık } \\
\text { Zorlar } \\
\text { Sinırı }\end{array}$} & 6 & 13 & 7 & 4 & 6 & 9 & 45 \\
\hline & $13,3 \%$ & $28,9 \%$ & $15,6 \%$ & $8,9 \%$ & $13,3 \%$ & $20,0 \%$ & $100,0 \%$ \\
\hline \multirow[t]{2}{*}{ Diğer } & 8 & 2 & 2 & 4 & 3 & 1 & 20 \\
\hline & $40,0 \%$ & $10,0 \%$ & $10,0 \%$ & $20,0 \%$ & $15,0 \%$ & $5,0 \%$ & $100,0 \%$ \\
\hline \multirow[t]{2}{*}{ Toplam } & 102 & 32 & 25 & 44 & 44 & 67 & 314 \\
\hline & $32,5 \%$ & $10,2 \%$ & $8,0 \%$ & $14,0 \%$ & $14,0 \%$ & $21,3 \%$ & $100,0 \%$ \\
\hline
\end{tabular}

Tablo 8'de "Sanayi sitesi nereye kurulmalıdır?" sorusuna verilen cevapların gruplara göre dağılımı yer almaktadır. Fethiye ilçesinin merkez ve Karaçulha mevkiinde faaliyet gösteren sanayi esnafinın görüşü incelendiğinde Fethiye Merkez Sanayi Sitesinde yer alan toplam 102 esnafin 81'i (\%37,5) Motokros Etkinliğinin Yapıldı̆̆ı Yer, 8'i (\%40) diğer, 7'si $(\% 21,2)$ Sarıkız Mevkii, 6'sı (\%13,3) Yakacık-Zorlar Sınırı; Karaçulha Sanayi Sitesinde yer alan toplam 32 esnafın 17'si $(\% 7,9)$ Motokros Etkinliğinin Yapıldı ̆̆ 1 Yer, 13'ü $(28,9)$ Yakacık Zorlar Sınırı, 2'si (\%10) ise diğer cevabını vermiştir. Sanayi mensuplarının görüşleri incelendiğinde en yüksek ortalama her iki sanayi sitesi için de "Motokros Etkinliğinin Yapıldığı Yer" olduğu görülmektedir.

Sanayi sitesinin taşınması durumunda dolaylı olarak etkilenecek grup olan merkez ve sanayi esnafının görüşleri incelendiğinde Fethiye merkezde yer alan toplam 25 esnafın 11'i $(\% 5,1)$ Motokros Etkinliğinin Yapıldığı Yer, 7'si (\%15,6) Yakacık Zorlar Sınırı, 5'i $(\% 15,2)$ Sarıkız Mevkii, ve 2'si (\%10) "diğer" cevabını verirken; AVM civarı toplam 44 (\%14) esnafın 28'i (\%13) Motokros Etkinliğinin Yapıldığı Yer, 8'i (\%24,2) Sarıkız Mevkii, 4'ü $(\% 8,9)$ Yakacık Zorlar Sınırı, 4'ü (\%20) diğer seçeneğini işaretlemiştir.

Sanayi sitesinin taşınması durumunda dolaylı olarak etkilenecek diğer bir grup olan vatandaşın görüşleri incelendiğinde Sanayi ve AVM civarında yer alan toplam 44 (\%14) esnafın 25'i (\%11,6) Motokros Etkinliğinin Yapıldığ 1 Yer, 10'u (\%30,3) Sarıkız Mevkii, 6's1 $(\% 13,3)$ Yakacık Zorlar Sınırı, 3'ü $(\% 15)$ ise diğer cevabını verirken; merkezde bulunan toplam $67(\% 21,3)$ vatandaşın 54'ü (\%25) Motokros Etkinliğinin Yapıldığ Yer, 9'u (\%20) Yakacık Zorlar Sınırı, 3'ü $(\% 9,1)$ Sarıkız Mevkii ve 1'i (\%5) "diğer" seçeneğini işaretlemiştir. 
Tablo 9: Sanayi Sitesinin Taşınacağı Yere İlişkin Görüşler ile Cinsiyet Durumunun Karşılaştırılması (t Testi Sonuçları)

\begin{tabular}{|l|l|l|l|l|l|l|}
\hline Cinsiyet & n & Ort. $(\bar{X})$ & s.s $(S)$ & s.d & t & p \\
\cline { 1 - 5 } Kadın & 43 & 1,5814 & 0,87 & 306 & 0,002 & 0,999 \\
\cline { 1 - 3 } Erkek & 265 & 1,5811 & 0,96 & & & \\
\hline
\end{tabular}

Tablo 9'da araştırmaya katılanların sanayi sitesinin taşınacağ yere ilişkin görüşleri ile cinsiyetleri arasında anlamlı bir farklılığın olup olmadığı test edilmektedir. Tabloda görüldüğü üzere karşılaştırmanın anlamlılık düzeyi 0.005 'ten büyüktür. Sanayi sitesinin taşınacağı yere ilişkin görüssler ile araştırmaya katılanların cinsiyetleri arasında anlamlı bir farklılık bulunmamıştır. "H1: Araştırmaya katılanların sanayi sitesinin taşınacağı yere ilişkin görüşleri cinsiyete göre anlamlı bir farklılık göstermektedir" hipotezi reddedilmektedir.

Tablo 10: Sanayi Sitesinin Taşınacağı Yere İlişkin Görüşler İle Mülkiyet Durumunun Karşılaştırılması

\begin{tabular}{|l|l|l|l|l|l|l|}
\hline Mülkiyet & n & Ort. $(\bar{X})$ & s.s $(S)$ & s.d & t & $\boldsymbol{p}$ \\
\hline Mülk Sahibi & 51 & 1,72 & 1,001 & 199 & 0,86 & 0,390 \\
\cline { 1 - 3 } Kirac1 & 150 & 1,58 & 0,991 & & & \\
\hline
\end{tabular}

Tablo 10'da araştırmaya katılanların sanayi sitesinin taşınacağı yere ilişkin görüşleri ile mülkiyet durumları arasında anlamlı bir farklılığın olup olmadığı test edilmektedir. Tabloda görüldüğü üzere karşılaştırmanın anlamlılık düzeyi 0.005 'ten büyüktür. Sanayi sitesinin taşınacağı yere ilişkin görüşler ile araştırmaya katılanların cinsiyetleri arasında anlamlı bir farklılık bulunmamıştır. "H2: Araştırmaya katılanların sanayi sitesinin taşınacağı yere ilişkin görüşleri mülkiyet durumlarına göre anlamlı bir farklılık göstermektedir" hipotezi reddedilmektedir.

Tablo 11: Sanayi Sitesinin Taşınacağı Yere İlişkin Görüşler İle Taşınma Kararlarının Karşılaştırılması

\begin{tabular}{|l|l|l|l|l|l|l|}
\hline Taşınmalı mı? & N & Ort. $(\bar{X})$ & s.s $(S)$ & s.d & t & p \\
\cline { 1 - 5 } Evet & 227 & 1,55 & 1,91 & 310 & 0,66 & 0,507 \\
\cline { 1 - 5 } & 85 & 1,63 & 1,044 & & & \\
\hline
\end{tabular}

Tablo 11'de araştırmaya katılanların sanayi sitesinin taşınacağ yer ile taşınma kararları arasında anlamlı bir farklılığın olup olmadığı test edilmektedir. Tabloda görüldügü üzere karşılaştırmanın anlamlılık düzeyi 0.005 'ten büyüktür. Sanayi sitesinin taşınacağ 1 yere ilişkin görüşler ile araştırmaya katılanların cinsiyetleri arasında anlamlı bir farklılık bulunmamıştır. "H3: Araştırmaya katılanların sanayi sitesinin taşınacağı yere ilişkin görüşleri taşınma kararlarına göre anlamlı bir farklılık göstermektedir" hipotezi reddedilmektedir.

Tablo 12: Sanayi Sitesinin Taşınacağı Yere İlişkin Görüşler İle İkinci Sanayi Sitesinin Açılmasına İlişsin Görüşırerin Karşılaştırılması

\begin{tabular}{|l|l|l|l|l|l|l|}
\hline İkinci bir site açılmalı mı? & N & Ort. $(\bar{X})$ & s.s $(S)$ & s.d & t & $\boldsymbol{p}$ \\
\hline Evet & 84 & 1,60 & 1,006 & 309 & 0,320 & 0,749 \\
\cline { 1 - 6 } Hayır & 227 & 1,56 & 1,568 & & & \\
\hline
\end{tabular}

Tablo 12'de araştırmaya katılanların sanayi sitesinin taşınacağı yere ilişkin görüşleri ile ikinci sanayi sitesinin kurulması görüşleri arasında anlamlı bir farklılığın olup olmadığı test edilmektedir. Tabloda görüldüğü üzere karşılaştırmanın anlamlılık düzeyi 0.005 'ten büyüktür. 
Sanayi sitesinin taşınacağı yere ilişkin görüşler ile araştırmaya katılanların cinsiyetleri arasında anlamlı bir farklılık bulunmamıştır. "H4: Araştırmaya katılanların sanayi sitesinin taşınacağı yere ilişkin görüşleri taşınma kararlarına göre anlamlı bir farklılık göstermektedir" hipotezi reddedilmektedir.

Tablo 13: Sanayi Sitesi Kurulumuna İlişkin Görüşlerin Eğitim Durumlarına Göre Karşıllaştırılması (Varyans Analizi)

\begin{tabular}{|c|c|c|c|c|c|c|c|}
\hline Eğitim Düzey & & $\mathbf{N}$ & & Ort & & SS & \\
\hline İlkokul & & 99 & & 1,535 & & 0,929 & \\
\hline Ortaokul & & 72 & & 1,597 & & 0,988 & \\
\hline Lise & & 85 & & 1,666 & & 0,881 & \\
\hline Ön Lisans & & 18 & & 1,750 & & 0,766 & \\
\hline Lisans & & 24 & & 3,000 & & 1,180 & \\
\hline Lisansüstü & & 1 & & 1,575 & & 0,242 & \\
\hline Toplam & & 299 & & 3,000 & & 0,943 & \\
\hline $\begin{array}{l}\text { VARYANS } \\
\text { KAYNAĞI }\end{array}$ & S.D. & & $\begin{array}{l}\text { KARELER } \\
\text { TOPLAMI }\end{array}$ & $\begin{array}{l}\text { KARELER } \\
\text { ORTALAMASI }\end{array}$ & $\mathbf{F}$ & & $p$ \\
\hline Genel & 298 & & 265,057 & & \multirow{3}{*}{\multicolumn{2}{|c|}{0,759}} & \multirow[t]{3}{*}{0,580} \\
\hline Gruplararas1 & 5 & & 3,388 & 0,678 & & & \\
\hline Gruplariçi & 293 & & 261,669 & 0,893 & & & \\
\hline
\end{tabular}

Tablo 13'de görüldüğü gibi Sanayi sitesi kurulumuna ilişkin görüşlerin Eğitim Durumlarına Göre karşılaştırılmasına ilişkin verilerin anlamlılık düzeyi 0,05'ten büyüktür. Hiçbir grup arasında anlamlı bir farklılık bulunmamıştır. ( $\mathrm{p}>0.05)$. Bu bağlamda H5 "Sanayi sitesi kurulumuna ilişkin görüş eğitim düzeyine göre anlamlı bir farklılık göstermektedir" hipotezi reddedilmektedir.

Tablo 14: Sanayi Sitesi Kurulumuna İlişkin Görüşlerin Yaş Aralıklarına Göre Karşılaştırılması (Varyans Analizi)

\begin{tabular}{|c|c|c|c|c|c|c|}
\hline Yaş aralığ & & $\mathbf{N}$ & & Ort & & SS \\
\hline 20 ve alt 1 & & 15 & & 1,666 & & 1,046 \\
\hline $21-30$ & & 59 & & 1,864 & & 1,090 \\
\hline $31-40$ & & 102 & & 1,431 & & 0,083 \\
\hline $41-50$ & & 87 & & 1,459 & & 0,095 \\
\hline $51-60$ & & 31 & & 1,709 & & 0,186 \\
\hline 61 ve üzeri & & 17 & & 1,705 & & 0,238 \\
\hline Toplam & & 311 & & 1,575 & & 0,053 \\
\hline $\begin{array}{l}\text { VARYANS } \\
\text { KAYNAĞI }\end{array}$ & S.D. & & $\begin{array}{l}\text { KARELER } \\
\text { TOPLAMI }\end{array}$ & $\begin{array}{l}\text { KARELER } \\
\text { ORTALAMASI }\end{array}$ & $\mathbf{F}$ & $\mathbf{p}$ \\
\hline Genel & 310 & & 279,974 & & 2,068 & 0,069 \\
\hline Gruplararas1 & 5 & & 9,180 & 1,836 & & \\
\hline Gruplariçi & 305 & & 270,794 & 0,888 & & \\
\hline
\end{tabular}

Tablo 14'de görüldüğü gibi sanayi sitesi kurulumuna ilişkin görüşlerin yaş aralığına göre karşılaştırılmasına ilişkin verilerin anlamlılık düzeyi 0,05 'ten büyüktür. Hiçbir grup arasında anlamlı bir farklılık bulunmamıştır. ( $p>0.05)$. Bu bağlamda H6 "Sanayi sitesi kurulumuna ilişkin görüş yaş aralığına göre anlamlı bir farklılık göstermektedir" hipotezi reddedilmektedir. 


\section{ARAŞTIRMANIN SONUÇLARI}

Fethiye Sanayi Sitesi'nin taşınmasına ilişkin paydaş görüşlerinin alındığı bu çalışmada Fethiye Sanayi Sitesi'nde araştırmaya katılan esnafın büyük bir kısmı erkek, 31-46 yaş aralığında, ilkokul mezunu, 5-20 yıl aralığında faaliyet göstermekte, işletmede 1 işçi çalıştırmakta ve kiracı olarak faaliyet göstermektedir.

Araştırmadan elde edilen veriler 1şı̆̆ında ankete katılan Karaçulha Sanayi Sitesinde faaliyet gösteren esnafın büyük bir kısmı erkek, 31-46 yaş aralığında, ilkokul mezunu, işletmede 1 kişi çalıştırmakta ve kiracı olarak faaliyet göstermektedir.

Genel toplamın "Evet" cevabını verdiği "Sanayi Sitesi taşınmalı mı?" sorusuna ilişkin grupların en yüksek frekans sonuçları aşağıdaki gibidir;

$>$ Fethiye Sanayi Sitesi esnafi: "Hayır"

$>$ Karaçulha Sanayi Sitesi esnafi: "Evet"

$>$ Fethiye Merkezde yer alan esnaf: "Evet"

$>$ Alışveriş merkezi civarı esnaf: "Evet"

$>$ Sanayi ve alışveriş merkezi civarı vatandaş: "Evet"

$>$ Merkezde bulunan vatandaş: "Evet"

Genel toplamın "Hayır" cevabını verdiği "İkinci bir sanayi Sitesi kurulmalı mı?" sorusuna ilişskin grupların en yüksek frekans sonuçları aşağıdaki gibidir;

> Fethiye Sanayi Sitesi esnafi: "Hayır"

$>$ Karaçulha Sanayi Sitesi esnafi: "Hayır"

$>$ Fethiye Merkezde yer alan esnaf: "Evet"

$>$ Alışveriş merkezi civarı esnaf: "Hayır"

$>$ Sanayi ve alışveriş merkezi civarı vatandaş: "Hayır"

$>$ Merkezde bulunan vatandaş: "Hayır"

Genel toplamın "Motokros Etkinliğinin Yapıldığı Yer" cevabını verdiği "Sanayi sitesi nerede kurulmalıdır?" sorusuna ilişkin grupların en yüksek frekans sonuçları aşağıdaki gibidir;

$>$ Fethiye Sanayi Sitesi esnafi: "Motokros Etkinliğinin Yapıldığı Yer"

$>$ Karaçulha Sanayi Sitesi esnafi: "Motokros Etkinliğinin Yapıldığı Yer"

$>$ Fethiye Merkezde yer alan esnaf: "Motokros Etkinliğinin Yapıldığı Yer"

$>$ Alışveriş merkezi civarı esnaf: "Motokros Etkinliğinin Yapıldığı Yer"

$>$ Sanayi ve alışveriş merkezi civarı vatandaş: "Motorkros Etkinliğinin Yapıldığı Yer"

$>$ Merkezde bulunan vatandaş: "Motokros Etkinliğinin Yapıldığı Yer"

"Sanayi Sitesi nerede kurulmalıdır?" sorusuna cevap veren 314 kişinin sonuçlarının dağılımı incelendiğinde ilk öneriler aşağıdaki gibidir;

1.Öneri: Motokros Etkinliğinin Yapıldığı Yer (216 kişi)

2. Öneri: Yakacık Zorlar Sınırı (45 kişi)

3. Öneri: Sarıkız Mevkii (33 kişi)

4. Öneri : Diğer (Karaçulha, Çatalarık, Çalıca, Çevreyolu, Seydikemer Zorlar Sınırı, Muğla Fethiye girişi, Çamköy, Değirmenbaşı) (20 kişi)

Araştırmaya katılanların çoğunluğu Sanayi Sitesinin taşınmasını, ikinci bir sanayi sitesi kuruması yerine tamamen taşınmasını ve sanayi sitesi için en uygun yerin "Motokros etkinliğinin yapıldığg yer" olduğunu düşünmektedir.

Araştırmaya katılan örneklemin sanayi sitesinin kurulacağı yere ilişkin görüşleri cinsiyete göre anlamlı bir farklılık göstermemektedir. Araştırmaya katılan örneklemin sanayi sitesinin kurulacağı yere ilişkin görüşleri işletmenin mülkiyet durumlarına göre anlamlı bir 
farklılık göstermemektedir. Araştırmaya katılanların sanayi sitesinin taşınacağ 1 yere ilişkin görüşleri taşınma kararlarına göre anlamlı bir farklılık göstermemektedir. Araştırmaya katılanların sanayi sitesinin taşınacağı yere ilişkin görüşleri ikinci bir sanayi sitesi açılmasına ilişkin görüşlerine göre anlamlı bir farklılık göstermemektedir. Sanayi sitesi kurulumuna ilişkin görüş eğitim düzeyine göre anlamlı bir farklılık gösterir. Sanayi sitesi kurulumuna ilişkin görüş yaş aralığına göre anlamlı bir farklılık göstermemektedir. Hipotez testleri sonuçlarına göre sanayi sitesinin taşınması istenmektedir. Taşınmasını istedikleri yerlerden en yüksek frekansa sahip olan Motorkros etkinliğinin yapıldığı yer sonucuna varılmıştır. Taşınması ve taşınmasını istedikleri yerler cinsiyete, eğitim durumuna, yaşa ve mülkiyet durumuna göre farklılık göstermemektedir.

Araştırma sonucunda "paydaş bakış açısı" bağlamında belirlenen üç alternatif kuruluş yerinden "Motokros etkinliğinin yapıldığı yer" seçilmiştir. Sanayi sitesinin yer değiştirmesi durumunda, yeni kuruluş yerinden doğrudan etkilenecek olan paydaş görüşlerinin alınmış olması çalışmaya önem katmaktadır. Fethiye'de yeni kurulacak sanayi sitesinin kuruluş yeri seçeneklerinin farklı yöntemler ile test edilmesi gelecekte yapılacak olan çalışmalara önerilmektedir.

\section{REFERENCES}

- Ar, İ. M., Baki, B. ve Özdemir, F. (2014). Kuruluş Yeri Seçiminde Bulanık Ahs-Vıkor Yaklaşımının Kullanımı: Otel Sektöründe Bir Uygulama, Uluslararası İktisadi ve İdari İncelemeler Dergisi, 7 (13): 93-114.

- ARIK, H., KARAARSLAN-BALIKÇI, N. ve ALABAŞ-USLU, Ç. (2012), "Maksimum Kapsama Modeliyle Tesis Yeri Seçimi: Perakende Sektöründe Bir Uygulama", Sakarya Üniversitesi Fen Bilimleri Dergisi, 16(1), 24-30.

- BAYÜLKEN, Y. ve KÜTÜKOĞLU, C. (2012) "Organize Snayi Bölgeleri, Küçük Sanayi Siteleri, Teknoparklar. Oda Raporu.

- BİRSEL, A. ve CERİT, G. (2009), "Lojistik İşletmelerin Kuruluş Yeri Seçiminde Arazi Faktörü”, İzmir Ulaşım Sempozyumu Bildiriler Kitabı, 8-9 Aralık, 432- 445.

- CHENG, E.W.L., LI, H. ve YU, L. (2005), "The Analytic Network Process (ANP) Approach to Location Selection: A Shopping Mall Illustration", Construction Innovation, 5, 83-97

- ÇATAY, B. (2011), “İstanbul'da İtfaiye İstasyonu Yer Seçiminde Risk Faktörüne Dayalı Bir Çoklu Kapsama Yaklaşımı”, Endüstri Mühendisliği Dergisi, 22(2), 33-44.

- ÇINAR, N.T. (2010), "Kuruluş Yeri Seçiminde Bulanık TOPSIS Yöntemi ve Bankacılık Sektöründe Bir Uygulama", KMÜ Sosyal ve Ekonomik Araştırmalar Dergisi, 12(18), 37-45.

- DEMİRDÖĞEN, O. ve BİLGİİ, B., (2004), "Organize Sanayi Bölgeleri İçin Yer Seçimi Kararlarını Etkileyen Faktörler: Erzurum Örneği”, Atatürk Üniversitesi Sosyal Bilimler Enstitüsü Dergisi, 4(2), 305-324.

- DONALSON T. ve PRESTON, L. E. (1995). "The stakeholder theory of the corporation: concepts, evidence, and implications'. Academy of Management Review, 20, 1: 65-91.

- ELEREN, A. (2006), "Kuruluş Yeri Seçiminin Analitik Hiyerarşi Yöntemi ile Belirlenmesi: Deri Sektörü Örneği”, Atatürk Üniversitesi İ̈BF Dergisi, 20(2), 405416. 
- ERTÜRK, M.(1995). İşletme Biliminin Temel İlkeleri, Beta Basım Yayın Dağıtım, İstanbul.

- FREEMAN, Edward, (1984), Strategic Management: A Stakeholder Approach, Pitman Inc., Boston, USA.

- FRIEDMAN, A. L. ve MILES, S. (2002). "Developing Stakeholder Theory". Journal of Management Studies, 39 (1):1-21.

- KÖKSAL, Y. ve EMRZA, E. (2011), "Kuruluş Yeri Açısından Cadde ve Alışveriş Merkezi Mağazacılığının Karşılaştırılması: Ankara İlinde Bir Araştırma”, Mustafa Kemal Üniversitesi Sosyal Bilimler Enstitüsü Dergisi, 8(16), 75-87.

- PADILlA, L. (2002), "Site Selection for Libraries", Libris Design project, http://www.librisdesign.org/docs/SiteSelectionLibraries.pdf, Erişim Tarihi: 21.03.2013.

- TENGÍlímOĞLU, D. (2001), "Hastane Seçimine Etkili Olan Faktörler: Bir Alan Uygulaması", Gazi Üniversitesi İIBF Dergisi, 85-98.

- TZENG, G-H., TENGA, M-H., CHENB, J-J. ve OPRICOVIC, S. (2002), "Multicriteria Selection for A Restaurant Location in Taipei", Hospitality Management, 21, 171-187.

- USTA, Ö. (1997). Yatırım Projeleri ve Değerlendirilmesi, Anadolu Matbaası, İzmir.

- XU, B., WEI, C., SHI, Z. ve YANG, L. (2009), "Study on Location-Selection of B2C E-Commerce Logistics Distribution Center", International Forum on Computer Science-Technology and Applications, 25-27 December, 7-10.

- YILDIZ, M. S. ve ŞAHİN, Ö. (2014). Teşvik Paketlerinin İşletmelerin Kuruluş Yeri Seçim Kararlarında Etkisinin Belirlenmesi: Düzce İli İmalat Sanayii İşletmelerinde Bir Araştırma. C.Ü. İktisadi ve İdari Bilimler Dergisi, 15(1): 1-19.

- FETHIYE, 2011, Kültür ve Turizm Bakanlığı Yayınları $<$ http://www.fethiye.gov.tr/ortak_icerik/fethiye/fethiyetr.pdf $>$ (Çevrimiçi 01.10.2014).

- FETHIYY KAYMAKAMLIĞI, <http://www.fethiye.gov.tr/ erişim tarihi> (Çevrimiçi 01.10.2014).

- FETHIYYE İŞLETME FAKÜLTESİ, <http://www.fethiye.mu.edu.tr/> (Çevrimiçi 14.11.2014).

- FETHIYY TURİZM DANIŞMA BÜROSU

- KÜltür VE TURIZM BAKANLIĞI, TANITMA GENEL MÜDÜRLÜĞÜ, $<$ http://www.kultur.gov.tr/> (Çevrimiçi 10.11.2014).

- 507 SAYILI ESNAF VE SANATKARLAR KANUNU http://www.tesk.org.tr/tr/5362/507.php

- MUĞLA İL KÜLTÜR VE TURİZM MÜDÜRLÜĞÜ. Turist Girișleri 2013. $<$ http://www.muglakulturturizm.gov.tr/TR,73713/2013.html > (Çevrimiçi 12.02.2014). 